\section{Stable isotopic indicators of diet from two Late Prehistoric burial sites in Portugal: an investigation of dietary evidence of social differentiation}

\section{Anna J. Waterman, ${ }^{1}$ Ana Maria Silva, ${ }^{2}$ Robert H. Tykot ${ }^{3}$}

'Department of Natural and Applied Sciences, Mount Mercy University, IA, USA; ${ }^{2}$ Department of Anthropology, University of Coimbra, Portugal; ${ }^{3}$ Department of Anthropology, University of South Florida, Tampa, USA

\section{Abstract}

This paper details the results of a comparison of stable isotopic data from bone samples acquired from 31 individuals from two Late Neolithic-Copper Age (3500-2000 BC) burial sites in the Estremadura region of Portugal. The chosen sites of Feteira II and Paimogo I are geographically close and temporally overlapping but represent distinctive types of burial structures, one being a natural cave and the other a tholos. Because stable isotope analyses can quantify individual dietary intake, it can be useful in distinguishing patterns of food consumption within and between populations. The goal of this research was to ascertain if there are dietary differences that would indicate that socially-differentiated populations were interred in these burial spaces. The results of this study indicate diets based primarily on $\mathrm{C}_{3}$ plants and terrestrial animals for both sampled populations. Although several individuals do exhibit dietary signatures that suggest they were consuming some fish, marine resources do not appear to be major dietary staples in either group despite close proximity to the sea. Some variation in food and water consumption is apparent between individuals at the two burial sites with individuals at Feteira II exhibiting more variability in isotopic indicators of dietary carbohydrates and drinking water sources while individuals from Paimogo I exhibit more variability in protein source and intake. However, no statistically significance differences in isotopic values were found that would point to clear dietary distinctions between the compared burial populations.

\section{Introduction}

This paper details the results of a study which compares stable isotopic data taken from
31 individuals from two Neolithic-Copper Age (3500-2000 BC) burials located near the city of Lourinhã in the Estremadura region of Portugal. In the past two decades stable isotope analyses on human skeletal remains recovered from archaeological sites has become a significant part of the archaeological toolkit because these analyses can provide an intra-lifetime record of the dietary and mobility patterns of individuals (Ambrose, 1993; Katzenberg and Harrison, 1997; Sealy, 2001; Tykot, 2006). In the field of archaeology researchers are primarily concerned with stable isotopic accumulations in teeth and bone as these hard tissues are taphonomically durable. Bone has two components; the first is a protein component called collagen, and the second is a mineral component called apatite (White, 2000). As a general rule, it is thought that the stable isotope ratios in bone collagen reflects the protein intake in the diet, while the stable isotope ratios in bone apatite is the result of a mixture of dietary features including proteins, carbohydrates, and lipids (Tykot, 2002). Bone is constantly undergoing remodeling processes as it responds to physiological growth, calcium homeostasis, and stress and strain. While different parts of the skeleton may turn over at slightly different rates, it is generally accepted that isotopic values in bone reflect the last ten years of an individual's life (Manolagas, 2000). For bone collagen, the calculations of $\delta^{13} \mathrm{C}$ and $\delta^{15} \mathrm{~N}$ values are the most common types of stable isotopic analysis completed in archaeological research as they can quantify animal and plant consumption in individuals and groups. In particular, these values allow researchers to distinguish between diets based upon terrestrial $v s$ marine proteins and $\mathrm{C}_{3}$ vs $\mathrm{C}_{4}$ plants (Schulting and Richards, 2001; Tykot, 2004). For bone apatite, $\delta^{13} \mathrm{C}$ and $\delta^{18} \mathrm{O}$ values are commonly used to investigate the relationships between plant and animal foods in the whole diet and to identify variations in drinking water sources. For example, comparisons between $\delta^{13} \mathrm{C}$ values in bone collagen and apatite can be used to determine the amount of consumed animal protein in diets (Lee-Thorp et al., 1989), as well as $\mathrm{C}_{3}$ vs $\mathrm{C}_{4}$ plants input (Kellner and Schoeninger, 2007). While $\delta^{18} 0$ values in bone apatite reflect water source and large variations within populations may be used to distinguish migrant individuals, examinations of $\delta^{18} 0$ values can also provide dietary data because a percentage of water is consumed in plant and animal foods. In particular, slight enrichment of $\delta^{18} 0$ values may signify the consumption of dairy products (Lai, 2008), or breast milk consumption in children (Wright and Schwarcz, 1998). Additionally, some enrichment may be attributable to $\mathrm{C}_{4}$ and CAM plants which tend to have higher $\delta^{18} 0$ values due to aspects of plant physiology related to drought resistance (Malainey, 2011).

Because stable isotope analyses can quanti-
Correspondence: Anna J. Waterman, Department of Natural and Applied Sciences, Mount Mercy University, 1330 Elmhurst Drive NE, Cedar Rapids, IA 52402, USA.

Tel/Fax: + 1.319.363.8213.

E-mail: awaterman@mtmercy.edu; anwaterman@gmail.com

Key words: stable isotope analysis, Portugal, diet, Neolithic.

Acknowledgments: the authors would like to thank Katina Lillios of the University of Iowa, Isabel Luna of the Museu Municipial de Torres Vedras and the Centro de Investigação em Antropologia e Saúde (CIAS) for help and support with this project and Cidália Duarte for generously providing access to the Feteira II skeletal materials. Additionally we would like to thank University of South Florida students Derek Clark and Shaina Smith for helping with the laboratory processing, and Ethan Goddard for running the samples on the mass spectrometers. Funds for this project were provided by the T. Anne Cleary Dissertation Fellowship and the Archaeological Institute of America Archaeology of Portugal Fellowship.

Citation: Waterman AJ, Silva AM, Tykot RH, 2014. Stable isotopic indicators of diet from two Late Prehistoric burial sites in Portugal: an investigation of dietary evidence of social differentiation. In: RH Tykot (ed.), Proceedings of the $38^{\text {th }}$ International Symposium on Archaeometry - May $10^{\text {th }}-14^{\text {th }} 2010$, Tampa, Florida. Open Journal of Archaeometry 2:5258.

Presented at the $38^{\text {th }}$ International Symposium on Archaeometry - May $10^{\text {th }}-14^{\text {th }} 2010$, Tampa, Florida.

This work is licensed under a Creative Commons Attribution 3.0 License (by-nc 3.0).

(C) Copyright A.J. Waterman et al., 2014

Licensee PAGEPress, Italy

Open Journal of Archaeometry 2014; 2:5258

doi:10.4081/arc.2014.5258

fy individual dietary intake it can be useful in distinguishing socially-differentiated patterns of diet within populations as well as across groups. Distinguishing such intra-group heterogeneity can be particularly important when evaluating middle-range societies - those with sociopolitical organisation between that of small-scale foraging groups and state-level societies (Feinman and Neitzel, 1984) - as it can provide evidence for culturally-mediated access to resources that otherwise would not be discernable in the archaeological record. During the Late Neolithic through Early Bronze Age (3500-1800 BC) the archaeological record for of the Portuguese Estremadura provides evidence of the development of a socially-complex, non-state society characterised by 
intensive agricultural production and the construction of large, fortified, hilltop settlements and labor-intensive megalithic collective tombs. This expansive period was followed by a time of socio-political devolution in the early Bronze Age in which the settlements and burial sites were abandoned (Lillios, 1993). Although it is generally agreed that some form of social differentiation began in this region during the Late Neolithic and that it increased over time, archaeologists have been unable to distinguish the exact nature of this differentiation (Gonçalves, 1994; Kunst, 1995; Lillios, 1995; Forenbaher, 1999; Chapman, 2003) or how sociopolitical organisation influenced societal collapse in the Early Bronze Age. One major impediment to studies of social differentiation in this time period is the collective burial practices which prevent the recognition of elite and non-elite individuals via grave goods because grave goods and the remains of multiple people are routinely commingled. Another hindrance is the diversity of burial spaces -such as natural and artificial caves, rockshelters, megaliths, and tholoi - which were used over hundreds of years and all house similar types of commingled burials. Because the constructed tombs (e.g. tholoi, megaliths and artificial caves) required substantial labor to build and often contain elaborate decorations and funerary goods, some scholars have theorised that at least some of these structures would be closely tied to high-status burials (Bueno Ramírez and Balbín Behrmann, 2006). It is well-documented that in many past and present societies, social class can dictate dietary patterns as well as access to material culture, with lower class individuals having limited access to high-quality protein or other statusrelated foods (Cohen, 1998; Darmon and Drewnowski, 2008). Although social differentiation may be difficult to distinguish through

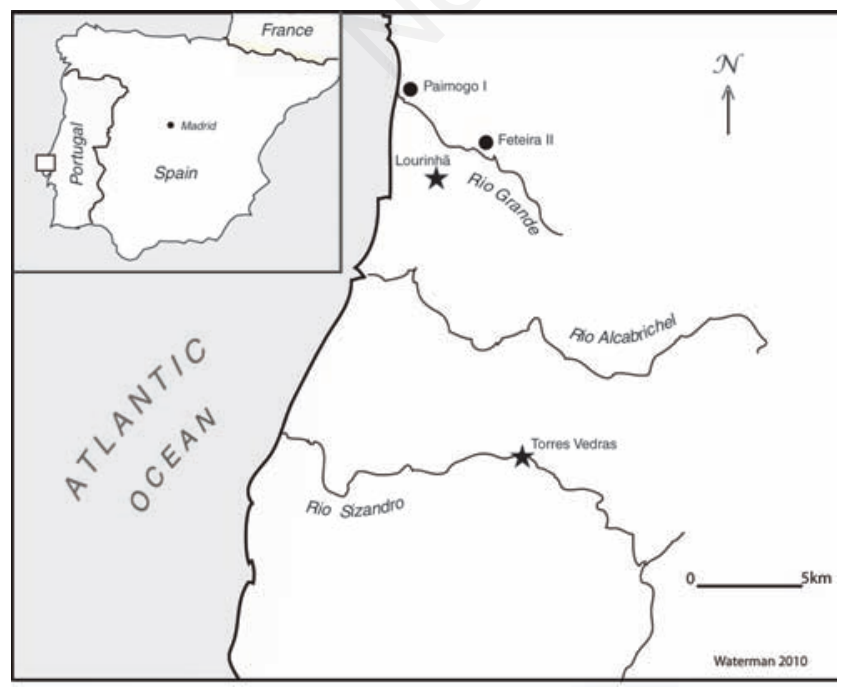

Figure 1. Map of Paimogo I and Feteira II. grave goods within the collective burials of Neolithic and Copper Age Portugal, if specific tombs are earmarked for particular portions of society these populations may exhibit measurable dietary differences. To investigate this possibility, two architecturally distinct but geographically close and temporally overlapping Late Neolithic-Copper Age burials were selected and stable isotope analysis was completed on multiple individuals from each site. The goal of this research was to ascertain if there is evidence of dietary differentiation in terms of three aspects: i) protein source (marine $v s$ terrestrial) or intake level; ii) carbohydrate source $\left(\mathrm{C}_{3}\right.$, vs $\mathrm{C}_{4}$ and $\mathrm{CAM}$ plants); and iii) drinking water source.

\section{Site information}

The Feteira burial cave is located near the city of Lourinhã in the Estremadura region of Portugal (Figure 1). This site was first discovered when a cave gallery (Feteira I) was exposed during a construction project in 1981 (Zilhão, 1984). Years later, another portion of the cave along with a substantial deposit of human remains, was discovered (Feteira II). The Feteira II burials were excavated by
Cidália Duarte of the former Instituto Português de Arqueologia in 1995-97. Arrowheads and beads recovered with the human remains were typologically consistent with the material culture of the Late Neolithic and radiocarbon dates on human bone reveal that individuals were being interred at this location between $c a$. 3700-2900 BC (Sac-1562, 1563) (Waterman, 2007). At this time only demographic information based upon dental analyses are available from Feteira II (Table 1). Based upon these analyses, Feteira II housed a minimum of 68 individuals, 26 of which are subadults (Waterman, 2007). For Feteira II the dental caries rate is 7.9 and $7.0 \%$ of the examined teeth exhibited at least one instance of dental enamel hypoplasia (Waterman, 2007).

Paimogo I is a corbel-vaulted tomb (tholos) located slightly west of Feteira II near the Atlantic coast. It was discovered in 1968 by Leonel Trindade and was excavated in 1971 (Gallay et al., 1973). Radiocarbon dates of $c a$. 3300-2500 BC for Paimogo I (Sac-1556) (Cunha et al., 2007) show that, although this site is slightly younger, its use-life overlaps with Feteira II. During excavations, archaeologists recovered an extensive array of grave
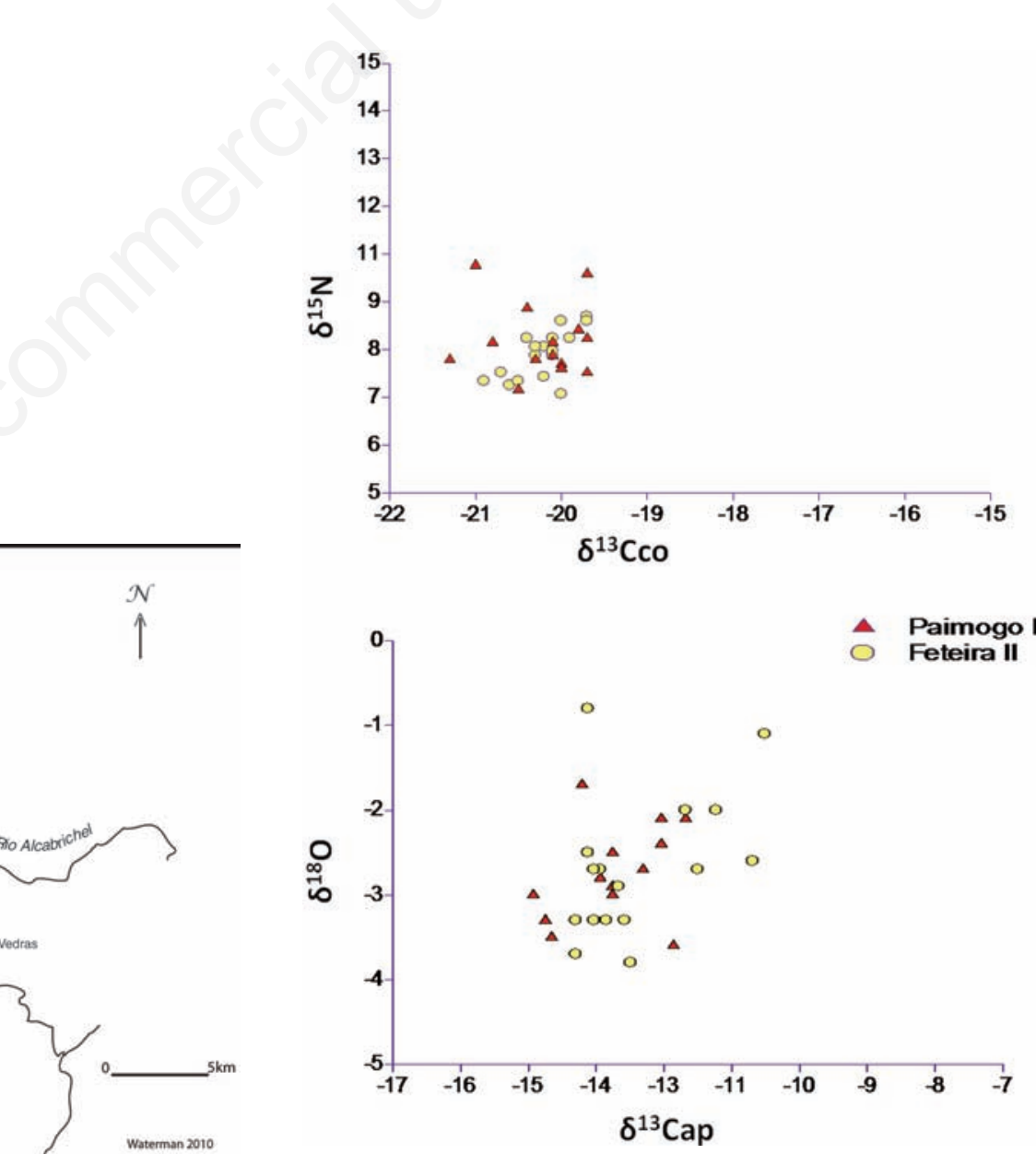

Figure 2. Scatter plots of isotopic values for Paimogo I and Feteira II individuals. 
goods from Paimogo I including some copper artifacts which may indicate some higher-status interments. Osteological analyses reveal that Paimogo I was an exceptionally large burial with a minimum of 413 individuals interred at this location, 123 of whom are classified as subadults (Silva, 2003b). Dental pathology rates are also available for Paimogo I, where a caries rate of $6.7 \%$ and a dental enamel hypoplasia rate of $1 \%$ has been calculated for permanent teeth (Figure 2) (Silva, 2003a, 2003b; Cunha et al., 2007).

\section{Materials and Methods}

As both skeletal collections are commingled and highly fragmented identifying distinct indi- viduals is problematic. For this reason, whole or partial mandibles were selected to represent most individuals in this project. Mandibles were chosen as the main unit of study as they could provide information about age-at-death as well as isotopic data. In total, bone samples were taken from 31 individuals (Table 1). These include samples from 13 adults and 4 children from Feteira II and samples from 8 adults, 3 adolescents and 3 children from Paimogo I. The subadult mandibles available from Feteira II were too fragmentary to provide adequate bone samples. Therefore, subadult femurs were substituted. Small bone fragments (1.5-4 g) were removed from each mandible (or femur) using a coping saw. Dental and/or skeletal development was used to estimate age ranges for subadults and individuals with extreme dental wear were categorised as older adults. Any visible dental pathology was also recorded. Because these skeletal remains come from commingled burials, in general it was not possible to determine the biological sex. However, in two cases extremely gracile adult mandibles have been tentatively identified as female. All bone fragments were further processed in the Laboratory for Archaeological Science at the University of South Florida. Bone collagen was extracted by demineralising whole bone using $2 \%$ hydrochloric acid for $72 \mathrm{~h}$, dissolving base-soluble contaminants using 0.1 M sodium hydroxide ( $24 \mathrm{~h}$ before and after demineralisation), and separating residual lipids with a mixture of methanol, chloroform and water for $24 \mathrm{~h}$. Collagen pseudomorphs were analysed for carbon and nitrogen isotopes using a CHN analysed coupled with a Finnigan MAT Delta Plus stable isotope ratio mass spec-

Table 1. Demographic data and sampled elements: Feteira II and Paimogo I.

\begin{tabular}{|c|c|c|c|c|c|}
\hline Site characteristics & Sample & Age grade & Sampled element & Dental pathology & Sex \\
\hline
\end{tabular}

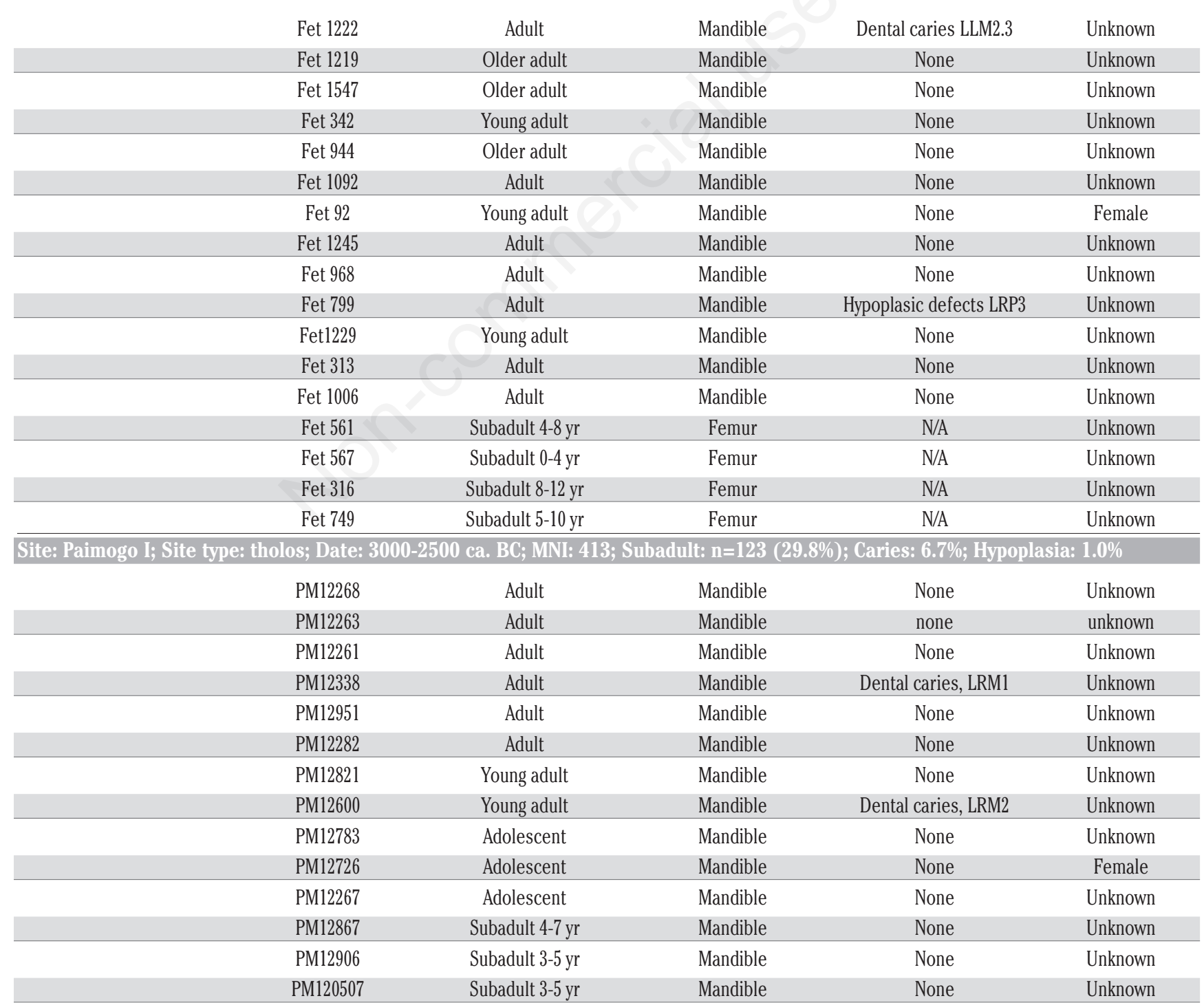


trometer using continuous flow. Along with visual analyses and data from the sample preparation, C:N ratios of the analysed gases were calculated to determine the preservation of collagen and the reliability of the isotope results. Apatite samples were also extracted using established techniques, with removal of organic components using sodium hypochlorite ( $24 \mathrm{~h}$ for enamel, $72 \mathrm{~h}$ for apatite), and of nonbiogenic carbonates using buffered $1 \mathrm{M}$ acetic acid $(24 \mathrm{~h})$. Apatite and enamel samples were analysed with a second Finnigan MAT Delta Plus instrument using a Kiel III device with $100 \%$ phosphoric acid at $90^{\circ} \mathrm{C}$. For both collagen and apatite results, carbon and nitrogen isotope ratios are reported using the delta $\left(^{*}\right)$ notation, in parts per mil (\%) relative to the PDB and AIR standards respectively. Further information on isotope analysis methods has been published elsewhere (Tykot, 2006).

\section{Results}

The results from the collagen and apatite analyses are presented in Table 2 and Figures 2 and 3. Apatite results were not available for one individual from each site due to machine error. Although the average values for the $\delta^{13} \mathrm{C}_{c 0}$ data are the same for both sites, $-20.2 \%$, Paimogo I exhibits a slightly larger range with a standard deviation of .05 . The $\delta^{15} \mathrm{~N}$ ratios also showed across-site cohesion with an average of $8.5 \pm 0.8 \%$ for Paimogo I and $8.2 \pm 0.5 \% 0$ for Feteira II, but again Paimogo I displays more variability with several individuals exhibiting $\delta^{15} \mathrm{~N}$ enrichments of 2-3\%0 when compared to other individuals at the same site. For the apatite data, Paimogo I demonstrates more internal cohesion while the data for Feteira II exhibits more variability. The average $\delta^{13} C_{a p}$ value for
Paimogo I was $-13.4 \pm 0.8 . \%$ while for Feteira II it was $-13.0 \pm 1.0 \%$. The increased variability in Feteira II is largely attributable to several individuals having enriched $\delta^{13} \mathrm{C}_{\text {ap }}$ values. While the average $\delta^{18} 0$ values were the same for both sites, $-2.7 \%$, once again Feteira II showed slightly more variation with a standard deviation of 0.9 compared to a standard deviation of 0.6 for Paimogo I. None of the datasets exhibited statistically significant differences between the two sites when compared using a two-sample t-test $\left(\delta^{13} \mathrm{C}_{\text {c0 }} \mathrm{P}=0.868, \delta^{15} \mathrm{~N} \mathrm{P}=0.226, \delta^{13} \mathrm{C}_{\text {ap }} \mathrm{P}=0.259\right.$, $\left.\delta^{18} 0 \mathrm{P}=0.802\right)$.

\section{Discussion}

In general, the collagen data suggests that all of the surveyed individuals ate diets based

Table 2. Isotopic values for Paimogo I and Feteira II individuals.

\begin{tabular}{|c|c|c|c|c|c|c|c|c|}
\hline Sample & Age grade & Lab \# & d13Cco & d15Nco & $\mathrm{C:N}$ & Lab \# & d13Cap & d180ap \\
\hline Fet 1222 & Adult & 12780 & -20.2 & 8.4 & 3.2 & 12794 & -10.9 & -1.1 \\
\hline Fet 1219 & Older adult & 12781 & -19.9 & 8.6 & 3.2 & 12795 & -14.0 & -3.7 \\
\hline Fet 1547 & Older adult & 12782 & -20.6 & 7.5 & 3.2 & 12796 & -13.8 & -0.8 \\
\hline Fet 342 & Young adult & 12783 & -20.4 & 8.6 & 3.2 & 12797 & -12.2 & -2.0 \\
\hline Fet 944 & Older adult & 12784 & -20.1 & 8.2 & 3.2 & 12798 & -13.5 & -3.3 \\
\hline Fet 1092 & Adult & 12785 & -19.7 & 9.1 & 3.2 & 12799 & -13.3 & -2.9 \\
\hline Fet 92 & Young adult & 12786 & -20.7 & 7.8 & 3.2 & 12800 & -12.0 & -2.7 \\
\hline Fet 1245 & Adult & 12787 & -20.5 & 7.6 & 3.2 & 12801 & -11.1 & -2.6 \\
\hline Fet 968 & Adult & 12788 & -20.1 & 8.3 & 3.2 & 12802 & - & - \\
\hline Fet 799 & Adult & 12789 & -20.3 & 8.2 & 3.2 & 12803 & -13.6 & -2.7 \\
\hline Fet1229 & Young adult & 13808 & -20.9 & 7.6 & 3.3 & 13825 & -13.1 & -3.8 \\
\hline Fet 313 & Adult & 13809 & -20.1 & 8.6 & 3.3 & 13826 & -13.7 & -3.3 \\
\hline Fet 1006 & Adult & 13810 & -20.0 & 9.0 & 3.2 & 13827 & -13.7 & -2.7 \\
\hline Fet 561 & Subadult 4-8 yr & 12790 & -20.3 & 8.4 & 3.2 & 12804 & -11.7 & -2.0 \\
\hline Fet 567 & Subadult 0-4 yr & 12791 & -19.7 & 9.0 & 3.2 & 12805 & -14.0 & -3.3 \\
\hline Fet 316 & Subadult 8-12 yr & 12792 & -20.0 & 7.3 & 3.2 & 12806 & -13.2 & -3.3 \\
\hline Fet 749 & Subadult $5-10 \mathrm{yr}$ & $\begin{array}{c}12793 \\
\text { ave } \\
\text { sd }\end{array}$ & $\begin{array}{c}-20.2 \\
-20.2 \\
0.3\end{array}$ & $\begin{array}{l}7.7 \\
8.2 \\
0.6\end{array}$ & 3.2 & 12807 & $\begin{array}{c}-13.8 \\
-13.0 \\
1.0\end{array}$ & $\begin{array}{l}-2.5 \\
-2.7 \\
0.9\end{array}$ \\
\hline PM12268 & Adult & 12749 & -21.3 & 8.1 & 3.2 & 12765 & -13.4 & -3.0 \\
\hline PM12263 & Adult & 12750 & -21.0 & 10.3 & 3.2 & 12766 & -12.9 & -2.7 \\
\hline PM12261 & Adult & 12751 & -20.4 & 9.3 & 3.2 & 12767 & -13.6 & -2.8 \\
\hline PM12338 & Adult & 12752 & -20.8 & 8.5 & 3.3 & 12768 & -14.5 & -3.3 \\
\hline PM12951 & Adult & 12754 & -19.8 & 8.8 & 3.2 & 12770 & -12.2 & -2.1 \\
\hline PM12282 & Adult & 12755 & -20.1 & 8.5 & 3.2 & 12771 & - & - \\
\hline PM12821 & Young adult & 12756 & -20.0 & 8.0 & 3.3 & 12772 & -14.7 & -3.0 \\
\hline PM12600 & Young adult & 12757 & -20.3 & 8.1 & 3.2 & 12773 & -13.4 & -2.9 \\
\hline PM12783 & Adolescent & 12760 & -19.7 & 7.8 & 3.2 & 12776 & -13.9 & -1.7 \\
\hline PM12726 & Adolescent & 12753 & -20.0 & 7.9 & 3.2 & 12769 & -14.4 & -3.5 \\
\hline PM12267 & Adolescent & 12748 & -19.7 & 10.1 & 3.2 & 12764 & -12.6 & -2.1 \\
\hline PM12867 & Subadult 4-7 yr & 12758 & -20.5 & 7.4 & 3.2 & 12774 & -13.4 & -2.5 \\
\hline PM12906 & Subadult 3-5 yr & 12759 & -20.1 & 8.2 & 3.2 & 12775 & -12.6 & -2.4 \\
\hline PM120507 & Subadult 3-5 yr & $\begin{array}{c}12761 \\
\text { ave } \\
\text { sd }\end{array}$ & $\begin{array}{c}-19.7 \\
-20.2 \\
0.5\end{array}$ & $\begin{array}{l}8.6 \\
8.5 \\
0.8\end{array}$ & 3.2 & 12777 & $\begin{array}{c}-12.4 \\
-13.4 \\
0.8\end{array}$ & $\begin{array}{c}-3.6 \\
-2.7 \\
0.6\end{array}$ \\
\hline
\end{tabular}


on $\mathrm{C}_{3}$ plants and terrestrial animal protein (Figure 4; Lai, 2008). It has been suggested that in isotopic markers of diet standard deviation of .03 or less point to populations with fairly homogenous diets (Lovell et al., 1986). By this standard, while generalised dietary patterns are similar between and within the surveyed populations, some minor heterogeneity does exist. For instance, subadults at both sites exhibit $\delta^{15} \mathrm{~N}$ values that trend toward the low or high ranges in comparison to adults. The subadults with the highest values tend to be the youngest children in the sample. For these children, the high $\delta^{15} \mathrm{~N}$ levels are most likely a product of breast milk consumption which is known to result in elevated $\delta^{15} \mathrm{~N}$ levels (Fuller et al., 2006). The low $\delta^{15} \mathrm{~N}$ levels for the older
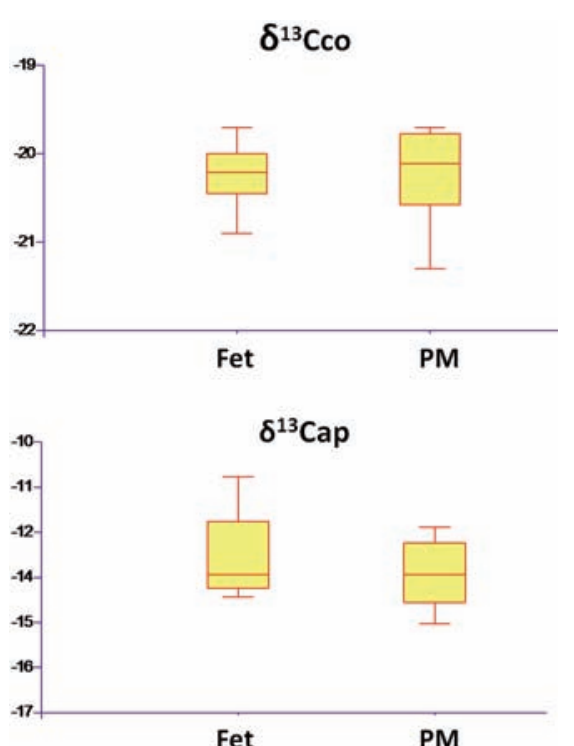

Fet

PM

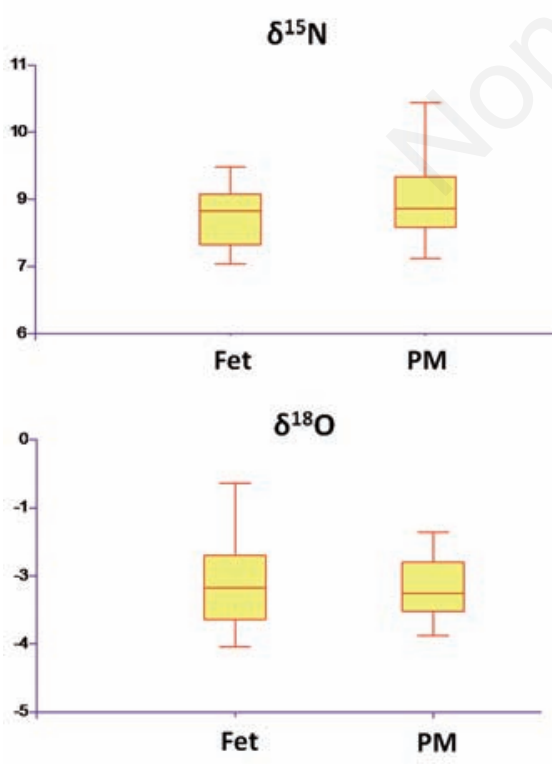

Figure 3. Box plots of isotopic values for Paimogo I and Feteira II individuals. children may indicate culturally mediated differences in adult and subadult diet in the population as a whole. Based upon the large numbers of children recovered from these burials it is evident that childhood mortality was high. Insufficient protein intake could have exacerbated other health-related issues and contributed to the high childhood mortality. Some variations in $\delta^{15} \mathrm{~N}$ values within the adult population are also apparent, most notably at Paimogo where several adults in the highest range exhibit 2-3\%0 enrichment over those at the lower end of the $\delta^{15} \mathrm{~N}$ values. This suggests that some adults were consuming significantly more meat, or meat from an animal that occupied a higher position in the food chain. Interestingly, the two tentatively identified females in this dataset both fall on the lower range for the $\delta^{15} \mathrm{~N}$ values which may suggest some gender-related dietary differentiation. At both sites, despite the estuary environment and the close proximity to the sea, there is little evidence that seafood was a main dietary staple. However, slightly higher $\delta^{15} \mathrm{~N}$ values in combination with higher $\delta^{13} C_{c o}$ for several adults in the sample (such as Fet 1092) does suggest that at least some individuals were consuming some fresh or saltwater fish.

Concerning the apatite results, in contrast to the collagen data the standard deviations for the $\delta^{13} C_{a p}$ values are larger for Feteira II than for Paimogo I. As apatite values reflect whole diet, these differences likely are a sign of more variability in plant intake within the Feteira II burial populations. In the Feteira II burial several individuals have enriched $\delta^{13} \mathrm{C}_{\mathrm{ap}}$ values (>-12) without having corresponding enriched $\delta^{13} \mathrm{C}_{\text {c } 0}$ or $\delta^{15} \mathrm{~N}$ values. Similar enrichments are not notable at Paimogo I. This suggests that the population interred at Feteira II may have had some $\mathrm{C}_{4}$ or CAM plant input in their diets. While the $\mathrm{C}_{4}$ plant millet is not thought to be present in Iberia until the Bronze Age (Rovira Buendía, 2007; Tafuri et al., 2009), it is possible that the data presented here marks its early introduction into Portugal. Another alternative is that people from Feteira II were incorporating seaweed or some other native $\mathrm{C}_{4}$ or CAM plant into their diets. Overall, the results from this study found cohesion in drinking water sources as $\delta^{18} 0$ values were similar at both sites. However, there was more variable in $\delta^{18} 0$ values at Feteira II with two individuals exhibiting particularly enriched values (Fet 1547, Fet 1222) suggesting that at least some people were consuming water from more disparate sources. At both sites enriched $\delta^{18} 0$ values appear to correlate with enriched $\delta^{13} C_{a p}$ values (Figure 4; Lai, 2008). This suggests that these dietary attributes may be tied together. $\mathrm{C}_{4}$ and CAM plants tend to have enriched $\delta^{18} 0$ values, therefore some of these variations may also be attributable to carbohydrates intake from $\mathrm{C}_{4}$ or CAM plants.

\section{Conclusions}

In sum, isotopic analyses were conducted on bone collagen and apatite from 17 individuals from the burial site of Feteira II and 14 individuals burial site of Paimogo I. Results from the study point to a diet mainly composed of terrestrial proteins and $\mathrm{C}_{3}$ plants for both sampled populations. Individual isotopic variation points to some heterogeneity in community diets, with particular adults consuming differ-

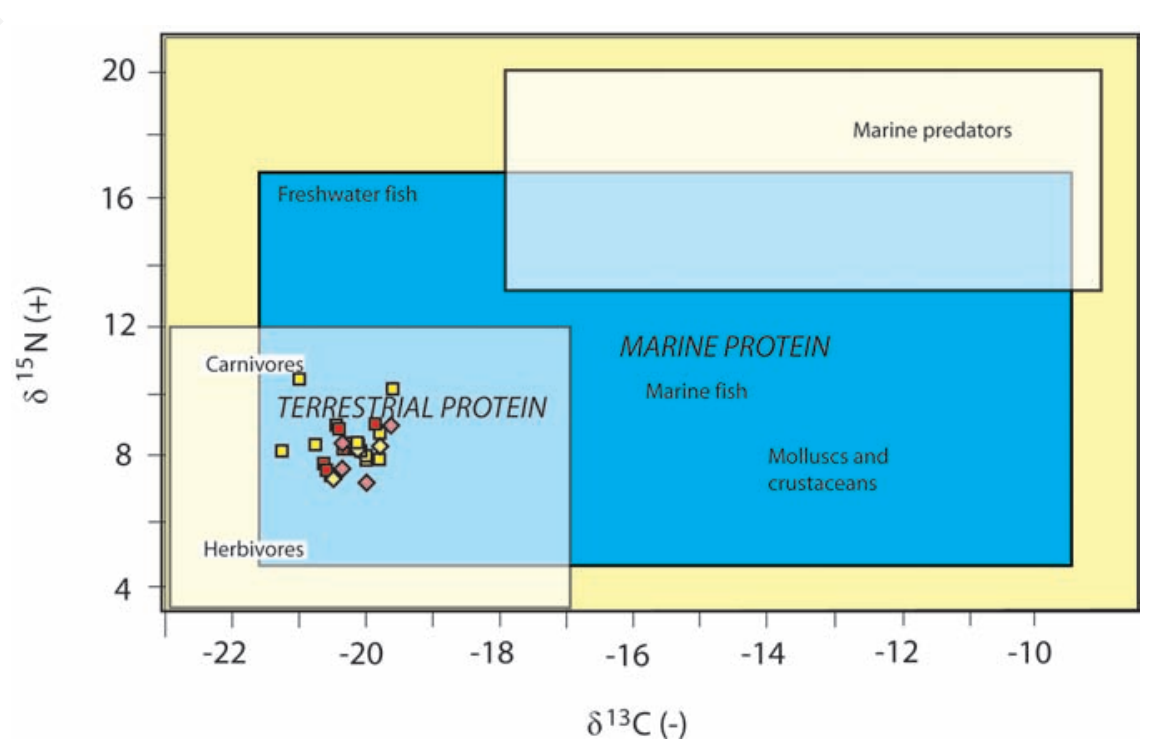

Figure 4. $\delta^{15} \mathrm{~N}$ and $\delta^{13} \mathrm{Cco}$ collagen values for individuals. Red markers denote Feteira II and yellow markers denote Paimogo I. Diamonds represent subadults. 
ential amounts of terrestrial animal protein, fish and/or $\mathrm{C}_{4}$ plants. However, while this study has documented some minor intra and extragroups variation in dietary breath, no statistically significance differences in isotopic values between the compared burial populations have been found that would indicate social differentiation in burial location. Broader comparisons of isotopic data from additional burials in this region are currently being undertaken to clarify these findings.

\section{References}

Ambrose SH, 1993. Isotopic analysis of paleodiets: methodological and interpretive considerations. In: M.K. Sandford (ed). Investigations of ancient tissue: chemical use in anthropology. Gordon and Breach, Langhorne, PA, pp 59-130.

Bueno Ramírez P, Balbín Behrmann R, 2006. Between power and mythology: evidence of social inequality and hierarchisation in Iberian megalithic art. In: P. Díaz-del-Río, L. García Sanjuán (eds.) Social inequality in Iberian late prehistory. Archaeopress, 0xford, pp 37-52.

Chapman R, 2003. Archaeologies of complexity. Routledge, London.

Cohen MN, 1998. The emergence of health and social inequalities in the archaeological record. In: S.S. Strickland, P.S. Shetty (eds.) Human biology and social inequality. Cambridge University Press, Cambridge, pp 58-75.

Cunha E, Umbelino C, Silva AM, Cardoso F, 2007. What can pathology say about the Mesolithic and Late Neolithic/Chalcolithic communities? the Portuguese case. In: M. Cohen, M. Gillian, Crane-Kramer, (eds.) Ancient health: skeletal indicators of agricultural and economic intensification. University Press of Florida, Gainesville, FL, pp 164-75.

Darmon N, Drewnowski A, 2008. Does social class predict diet quality? Am J Clin Nutr 87:1107-17.

Feinman G, Neitzel J, 1984. Too many types: an overview of sedentary prestate societies in the Americas. in: M.B. Schiffer (ed.) Advances in Archaeological Method and Theory. Academic Press, Orlando, pp 39102.

Forenbaher S, 1999. Production and exchange of bifacial flaked stone artifacts during the Portuguese Chalcolithic. Archaeopress, Oxford.

Fuller BT, Fuller JL, Harris DA, Hedges REM, 2006. Detection of breastfeeding and weaning in modern human infants with carbon and nitrogen stable isotope ratios. Am J Phys Anthropol 129:279-93.
Gallay G, Spindler K, Trindade L, Ferreira ODV, 1973. [0 monumento pré-histórico de Paimogo I (Lourinhã)]. [Book in Portuguese]. Associação dos Arqueólogos Portugueses ed., Lisbon.

Gonçalves VS, 1994. [A primeira metade do $3^{\circ}$ milenio no centro/Sul de Portugal: algumas sreves reflexôes, enquanto outras nâo são posiveis. Trabalhos de Arqueologia e Etnologia]. [Proc. in Portuguese]. [Actas de $1^{\circ}$ Congresso Peninsular de Arqueologica Vol 4]. 34:117-31.

Katzenberg MA, Harrison RG, 1997. What's in a bone? Recent advances in archaeological bone chemistry. J Archaeol Res 5:265-93.

Kellner CM, Schoeninger MJ, 2007. A simple carbon isotope model for reconstructing prehistoric human diet. Am J Phys Anthropol 133:1112-27.

Kunst M, 1995. Central places and social complexity in the Iberian Copper Age. In: K.T. Lillios (ed.) The origins of complex societies in late prehistoric Iberia. International Monographs in Prehistory, Ann Arbor, MI, pp 32-43.

Lai L, 2008. The interplay of economic, climatic and cultural change investigated through isotopic analyses of bone tissue: the case of Sardinia 4000-1900 B.C. (PhD dissertation). University of South Florida, Tampa.

Lee-Thorp JA, Sealy JC, van der Merwe NJ, 1989. Stable carbon isotope ratio differences between bone-collagen and bone apatite, and their relationship to diet. J Archaeol Sci 16:585-99.

Lillios KT, 1993. Regional settlement abandonment at the end of the Copper Age in the lowlands of west-central Portugal In: C. Cameron, S. Tomka (eds.) Abandonment of settlements and regions: ethno-archaeological and archaeological approaches. Cambridge University Press, Cambridge, pp 110-20.

Lillios KT, 1995. The historiography of late prehistoric Portugal. In: K.T. Lillios (ed.) The origins of complex societies in late prehistoric Iberia. International Monographs in Prehistory, Ann Arbor, pp 7-19.

Lovell NC, Nelson DE, Schwarcz HP, 1986. Carbon isotope ratios in palaeodiet: lack of age or sex effect. Archaeometry 28:51-5.

Malainey ME, 2011. A consumer's guide to archaeological science: analytical techniques. Springer, New York.

Manolagas SC, 2000. Birth and death of bone cells: basic regulatory mechanisms and implications for the pathogenesis and treatment of osteoporosis. Endocr Rev 21:115-37.

Rovira Buendía N, 2007. [Agricultura y gestión de los recursos vegetales en el sureste de la península ibérica durante la prehistoria reciente]. [PhD dissertation in Spanish]. Universitat Pompeu Fabra ed., Barcelona.
Schulting RJ, Richards MP, 2001. Dating women and becoming farmers: new palaeodietary and AMS dating evidence from the Breton Mesolithic cemeteries of Teviec and Hoedic. J Anthropol Archaeol 20:314-44.

Sealy J, 2001. Body tissue chemistry and Palaeodiet. In: D.R. Brothwell, A.M. Pollard (ed.) Handbook of archaeological sciences. John Wiley and Sons, Chichester, pp 269-79.

Silva AM, 2003a. Physiological stress in a late Neolithic/Chalcolithic Portuguese population: the case of Paimogo I (Lourinhã, Portugal). In: M.P Aluja, A. Malgosa, R.M. Nogués (eds.) Antropología y biodiversidad actas do XII congreso de la sociedad española de antropología biológica. Bellaterra ed., Barcelona, pp 506-12.

Silva AM, 2003b. Portuguese populations of Late Neolithic and Chalcolithic periods exhumed from collective burials: an overview. Anthropologie 1-2:55-64.

Tafuri MA, Craig OE, Canci A, 2009. Stable isotope evidence for the consumption of millet and other plants in Bronze Age Italy. Am J Phys Anthropol 139:146-53.

Tykot RH, 2002. Contribution of stable isotope analysis to understanding dietary variation among the Maya. In: K. Jakes (ed.) Archaeological chemistry: materials, methods, and meaning. American Chemical Society, Washington, DC, pp 214-30.

Tykot RH, 2004. Stable isotopes and diet: you are what you eat. In: M. Martini, M. Milazzo, M. Piacentini (eds.) Physics methods in archaeometry. Proceedings of the International School of Physics Enrico Fermi Course CLIV. Società Italiana di Fisica ed., Bologna, pp 433-44.

Tykot RH, 2006. Isotope analyses and the histories of maize. In: J.E. Staller, R.H. Tykot, B.F. Benz (eds.) Histories of maize: multidisciplinary approaches to the prehistory, linguistics, biogeography, domestication, and evolution of maize. Academic Press, New York, pp 131-42.

Waterman AJ, 2007. Health status in prehistoric Portugal: dental pathology and childhood mortality patterns from the Late Neolithic burials of Feteira (Lourinhã). Am J Phys Anthropol 132(Supp.44):245.

White TD, 2000. Human osteology. Academic Press, San Diego.

Wright LE, Schwarcz HP, 1998. Stable carbon and oxygen isotopes in human tooth enamel: identifying breastfeeding and weaning in prehistory. Am J Phys Anthropol 106:1-18.

Zilhão J, 1984. [A gruta da Feteira (Lourinhã)]. [Book in Portuguese]. Ministério da Cultura, Instituto Português do Património Cultural ed., Lisbon. 